Maria Fernanda F. Lima-Costa 1,2,3

Henrique L. Guerra 1,2

Josélia O. A. Firmo 1,2

Pedro G. Vidigal 1,2,3

Elizabeth Uchoa 1,2,3

Sandhi M. Barreto 1,2,3

\section{The Bambuí Health and Aging Study (BHAS): private health plan and medical care utilization by older adults}

\author{
Projeto Bambuí: plano privado de saúde \\ e utilização de serviços médicos pela \\ população idosa
}

1 Núcleo de Estudos em Epidemiologia e Antropologia do Envelhecimento, Centro de Pesquisas René Rachou, Fundação Oswaldo Cruz. Av. Augusto de Lima 1715, Belo Horizonte, $M G$ 30190-002, Brasil.

lima-costa@cpqrr.fiocruz.br

2 Laboratório de Epidemiologia e Antropologia Médica, Centro de Pesquisas René Rachou, Fundação Oswaldo Cruz. Av. Augusto de Lima 1715, Belo Horizonte, $M G$ 30190-002, Brasil.

3 Faculdade de Medicina Universidade Federal de Minas Gerais. Av. Alfredo Balena 190, Belo Horizonte, $M G$ 30130-100, Brasil.

\begin{abstract}
The aim of this cross sectional study was to investigate whether holding a private health plan affects the consumption of medical services (hospitalization and visits to a doctor) and use of medications by older adults. All residents in Bambuí town (Minas Gerais, Brazil) aged $\geq 60$ years $(n=1,742)$ were selected. From these, $92.2 \%$ were interviewed and $85.9 \%$ were examined (blood tests and physical measurements). After adjustments for counfounders, those under exclusive public coverage $(n=1,296)$, compared with those holding a private health plan $(n=$ 310), presented some evidence of having worse health status, reported less visits to a doctor, and used a small number of prescribed medications. The main explanation for the aged holding a private health plan was economic, not health. Even though those who had only public health coverage complained more in relation to medical care (70.9\%), an important proportion of the aged with a private health care plan presented some kind of complaint (45.2\%). Another worrying factor was the difficulty to acquire medication because of financial problems (47.2 and $25.2 \%$ reported, respectively). Further investigations are needed to verify whether our results can be generalized to other communities of the country.
\end{abstract}

Key words Aged; Drugs; Health Services

Resumo O objetivo deste estudo seccional foi investigar se a cobertura de um plano privado de saúde afeta o uso de serviços médicos (consultas e hospitalizações) e o consumo de medicamentos entre idosos. Todos os residentes na cidade de Bambuí (Minas Gerais) com idade $\geq 60$ anos ( $n=$ 1.742) foram selecionados. Destes, 92,2\% e 85,9\% foram entrevistados e examinados (exames de sangue e medidas físicas), respectivamente. Após ajustamentos por variáveis de confusão, os idosos que dependiam dos serviços públicos $(n=1.296)$, em comparação aos que possuíam plano privado de saúde $(n=310)$, apresentaram evidências de pior condição de saúde, visitaram menos o médico e usaram menor número de medicamentos prescritos. A principal explicação para a cobertura de um plano privado foi econômica e não a condição de saúde. Embora a proporção dos que se queixaram dos serviços médicos tenha sido mais alta entre os que dependiam dos serviços públicos (70,9\%), esta queixa também foi importante entre os que possuíam plano de saúde privado (45,2\% relataram). O relato de dificuldades para adquirir medicamentos devido a problemas financeiros foi alto (25,2 e 47,2\%). Novas investigações são necessárias para determinar se estes resultados são generalizáveis para outras comunidades do país.

Palavras-chave Idoso; Medicamento; Serviços de Saúde 


\section{Introduction}

The ageing population, first observed in developed countries, is now also a phenomenon in the developing world. It is estimated that Brazil will be among the top ten countries in size of elderly inhabitants in 2025, with an estimated population of about 27 million people aged $\geq 60$ years (WHO, 1998). In five years (1991-1996), the number of elderly in the country increased $8.2 \%$ or 1.6 million people (IBGE, 1996). An important consequence of this expanding population is an increasing demand for health and social services. A measurable impact of the increase of the elderly population is evident for instance in the use of hospitals in Brazil. In 1996, those aged $\geq 60$ years made up about $22.9 \%$ (US\$ 659 million) of the Brazilian public expenditure on hospital care, even though they accounted for $7.9 \%$ of the population (DATASUS, 1996; IBGE, 1996).

Brazil has the Sistema Único de Saúde (SUS) which is public and provides gratuitous and universal access to comprehensive health care services. The SUS covers $75 \%$ of the Brazilian population. In addition, some individuals have private supplemental coverage: in $1995,20 \%$ of the population (around 34 million persons) had private health insurance or health plans (OPAS/ OMS, 1998). There is consistent evidence that additional private coverage among older adults is associated with increased health service use (Cohen et al., 1997; Hurd \& McGarry, 1997; Link et al., 1980; McCall et al., 1991). We do not know, however, whether this evidence, based on studies carried out in developed countries, can be generalized to developing countries.

The objective of this study was to investigate whether holding an additional private coverage affects the consumption of medical service (hospitalization and visits to a doctor) and use of medications (prescribed and nonprescribed) in a Brazilian community. We used data from the baseline of The Bambui Health and Ageing Study (BHAS), which is a population based prospective study of older adults carried out in the town of Bambui, Minas Gerais State, Southeast Brazil (Lima-Costa et al., 2000). In order to avoid that any possible association between health plan status, and use of health service was influenced by adverse health selection of those holding a private coverage (Hellinger, 1995; Hurd \& McGarry, 1997), we investigated the relationship between private health plan status and several indicators of health status. So, an additional objective of the present study was to quantify the importance of adverse health selection in holding a private health plan among older adults.

\section{Material and methods}

\section{Study area}

The Municipality of Bambuí comprises 20,573 inhabitants, $73 \%$ of those living in the urban area (Bambuí town) of the municipality in 1991. The index of Human Development in the community was 0.70 , life expectancy was 70.2 years and $75 \%$ of the deaths were of people aged $\geq 50$ years in 1990-91 (Lima-Costa et al., 2000). The main causes of death for the population in this municipality were stroke (ICD-10: I60-I69), Chagas disease (ICD-10: B57), ischaemic heart disease (ICD-10: I-20-I25), and pulmonary chronic obstructive disease (ICD10: J43, J44) (death rates $=118.0,61.4,42.5$ and 18.9 per 100,000 inhabitants, respectively) (DATASUS, 1996; IBGE, 1996). The high mortality due do Chagas disease among residents in this community is the consequence of their past exposure to Trypanosoma cruzi infection. Infection transmission appears to have been interrupted around 20 years ago, but seropositivity for T. cruzi remains high among older inhabitants due to cohort effect (Lima-Costa et al., 2001).

The town has one general hospital with 62 beds and a municipal outpatient clinic with a 24-hours first-aid sector. Some medications are distributed free by the local public SUS, but provisions are variable and erratic. In 1996 there was one doctor per 1,000 inhabitants in the town (H. L. Guerra, personal communication).

\section{Study population}

A complete census was carried out in Bambuí town in November and December 1996 for identification of older adult (aged $\geq 60$ years) participants in the baseline of the Bambui cohort study. All residents of this age were selected for interview, physical measurements and blood tests. Of 1,742 residents aged $\geq 60$ years, $92.2 \%$ participated in the interview and $85.9 \%$ were examined (blood tests and physical measurements). Participants in the interview and in the examinations were similar to the town population of this age in all the characteristics considered: age, gender, number of residents in the household, marital status, family income and education (Lima-Costa et al., 2000).

\section{Interview}

The following variables from the baseline BHAS interview were considered in this study: (1) sociodemographic characteristics (age, gen- 
der, number of years of schooling and monthly family income), (2) medical history for selected diseases diagnosis (has a doctor ever said you had: angina pectoris, myocardial infarction, diabetes or other chronic condition); (3) selected indicators of social support or social ties (satisfaction with social network, satisfaction with free time arrangements and presence of an informal caregiver); (4) lifestyle (lifetime smoking habits and frequency of alcohol consumption in past 12 months); (5) self-rated health in previous 6 months; (6) selected measures of physical performance (level of difficulty to walk 300 meters and ability to perform at least one of the following activities of daily living: bathing, dressing, transferring from bed to chair, using the toilet or eating); (7) other health status indicators (impossibility to perform any routine activity because of a health problem in past 2 weeks, and staying in bed during past 2 weeks); (8) use of health care facilities (visits to doctors in past 12 months and hospitalization for at least one night in past 12 months); (9) use of medications (number of prescribed and non prescribed medications in previous 3 months); (10) main reason for dissatisfaction when seeking medical care or medication; (11) source of health care (private health plan or public SUS only).

When a respondent was unable to participate because of cognitive deficit or for some other health reason, an appropriate proxy was used (Nelson et al., 1990). They were not asked questions that required personal judgement, such as self-rated health, satisfaction with social network or satisfaction with free time arrangements (Lima-Costa et al., 2000).

\section{Blood pressure and anthropometric measurements}

Blood pressure measurements (BP) were performed 30 or more minutes after the last caffeine intake or cigarette smoked, and three measures were taken after 5 minutes of initial rest and subsequently at 2-minute interval (Anonymous, 1993). In this study BP was considered as the arithmetic mean of the second and third measurements. The nutritional indicator used was body mass index (weight/square height). All measures were performed by specially trained health technicians, using standard equipments (Lima-Costa et al., 2000).

\section{Blood tests}

Serum samples of all participants in this study were investigated for the presence of $T$. cruzi antibodies by two commercial assays, an indirect hemaglutination assay (IHA) and an enzyme-linked immunoabsorbent assay (ELISA) (Biolab and Abbott Laboratories, Brazil, respectively); seropositivity was defined when the two samples showed positive results. Blood tests included biochemical analysis for total cholesterol, HDL cholesterol and tryglicerides, using an automated analyzer (Eclipse Vitalab, Merck, Netherlands).

Interviews, physical measurements, blood samples and blood tests of all participants were accomplished between January and August 1997. A free and signed informed consent of all participants was obtained. Further details are described elsewhere (Lima-Costa et al., 2000).

\section{Data analysis}

Crude analysis was based on the Wilcoxon rank test (for medians) and on Pearson chi-square or chi-square test for linear trend (for proportions) (Armitage \& Berry, 1987). Multivariate analysis was based on the adjusted odds ratios and their 95\% confidence intervals (Woolf's method); odds ratios were adjusted using multivariate logistic regression method (Hosmer \& Lemenshow, 1989). All variables associated with holding a private health plan beyond 0.20 level in the univariate analysis were included in the initial logistic model (Greenland, 1989). When two variables were highly correlated, such as schooling and monthly family income, only the one strongly related with private health plan status (schooling) was included in the logistic model. The analysis was carried out using the Stata statistical software (Stata Corporation, 1997).

\section{Results}

Among the 1,606 participants in this study, 310 (19.3\%) had private health plan and 1,296 (80.7\%) were exclusively under the SUS public cover. Among the former, 134 individuals were covered by employment based health plan, 115 were covered by medical co-operative and 61 were covered by other types of private health plan.

The distribution of sociodemographic characteristics according to private health plan status is shown in Table 1. Educational level ( $\mathrm{p}<$ $0.001)$ and monthly family income $(\mathrm{p}<0.001)$ were both significantly associated with holding private health plan. No significant associations between gender $(\mathrm{p}=0.202)$ or age $(\mathrm{p}=0.804)$ and private health plan status were found. 
Table 1

Distribution of selected sociodemographic characteristics among older adults, according to private health plan status. Bambui, Minas Gerais State, Brazil, 1997.

\begin{tabular}{|c|c|c|}
\hline \multirow{2}{*}{$\begin{array}{l}\text { Sociodemographic } \\
\text { characteristics }\end{array}$} & \multicolumn{2}{|c|}{ Private health plan (\%) } \\
\hline & Yes $(n=310)$ & No $(n=1,296)$ \\
\hline \multicolumn{3}{|l|}{ Gender } \\
\hline Male & 43.2 & 39.3 \\
\hline Female & 56.8 & 60.7 \\
\hline & \multicolumn{2}{|c|}{$p=0.202$} \\
\hline \multicolumn{3}{|l|}{ Age (years) } \\
\hline $60-64$ & 34.8 & 32.3 \\
\hline $65-69$ & 24.8 & 25.4 \\
\hline $70-74$ & 19.0 & 18.9 \\
\hline$\geq 75$ & 21.3 & 23.4 \\
\hline & \multicolumn{2}{|c|}{$p=0.804$} \\
\hline \multicolumn{3}{|l|}{ Schooling (years) } \\
\hline None & 13.2 & 37.1 \\
\hline $1-3$ & 22.9 & 35.0 \\
\hline $4-7$ & 38.4 & 24.1 \\
\hline$\geq 8$ & 25.2 & 3.4 \\
\hline Not informed & 0.3 & 0.4 \\
\hline & \multicolumn{2}{|c|}{$p^{\prime}<0.001$} \\
\hline \multicolumn{3}{|c|}{ Monthly family income* } \\
\hline$<2.0$ & 13.2 & 33.6 \\
\hline $2.0-3.9$ & 25.5 & 40.4 \\
\hline $4.0-5.9$ & 18.1 & 14.0 \\
\hline$\geq 6.0$ & 42.9 & 10.9 \\
\hline Not informed & 0.3 & 1.2 \\
\hline \multicolumn{3}{|c|}{$p^{\prime}<0.001$} \\
\hline
\end{tabular}

* in Brazilian minimum wages (each $=$ US $\$ 120.00$ during the study period) $p=p$ value (Pearson's chi square test)

$p^{\prime}=p$ value (chi square for linear trend) health conditions are presented in Table 3. Seroposivity for T. cruzi was less frequent among those under private coverage $(\mathrm{p}<0.001)$. Median body mass index was higher among those who had a private health plan $(\mathrm{p}=0.001)$. No significant differences between those with and without private health coverage were found regarding median systolic blood pressure $(\mathrm{p}=$ $0.218)$, median diastolic blood pressure $(\mathrm{p}=$ $0.254)$, total cholesterol ( $\mathrm{p}=0.834)$, HDL cholesterol $(\mathrm{p}=0.937)$ or triglycerides level $(\mathrm{p}=$ 0.265).

No association between satisfaction with social network ( $p=0.288$ ), satisfaction with free time arrangements $(p=0.535)$, presence of an informal caregiver $(p=0.981)$ or frequency of alcohol consumption during past 12 months $(\mathrm{p}=0.188)$ and private health plan status was found. Current smoking was less frequent among those who had private coverage in comparison with those without it $(26.1$ and $11.9 \%$ vs. 22.3 and $20.5 \%$ were ex-smokers or still smoked, respectively; $\mathrm{p}=0.008$ ).

Table 4 shows the distribution of number of visits to a doctor, number of hospitalizations in past 12 months, and number of prescribed and non prescribed medications used in past 3 months, according to health plan status. The number of visits to a doctor were significantly higher among those with private coverage $(\mathrm{p}=$ 0.010 ). Those who had private coverage used more prescribed $(\mathrm{p}<0.001)$ and non-prescribed $(\mathrm{p}=0.010)$ medications. A higher proportion of those under exclusive public coverage had two or more hospitalisations in past 12 months (7.8 vs. $3.9 \%$ ), but the difference was at the borderline of significance $(\mathrm{p}=0.056)$.

Significant results $(p<0.05)$ of the multivariate analysis of factors associated with holding a private health plan are presented in Table 5. Education was the factor most strongly associated with holding a private coverage: ${ }_{\text {Adj }} \mathrm{OR}=$ 1.60 (95\%CI: 1.06-2.41), ${ }_{\mathrm{Adj}} \mathrm{OR}=13.82$ (95\% CI: 2.58-5.66), and ${ }_{\mathrm{Adj}} \mathrm{OR}=16.10$ (95\%CI: 9.6926.76) for those with $1-3,4-7$ and $\geq 8$ years of schooling, respectively. Older adults covered by private health plan were less likely to perceive their health as bad/very bad $\left(_{\text {Adj }} \mathrm{OR}=0.47\right.$; 95\%CI: $0.30,0.73)$, to need a proxy respondent $\left({ }_{\text {Adj }} \mathrm{OR}=0.11 ; 95 \% \mathrm{CI}: 0.03,0.47\right.$ ), as well as to report inability to perform routine activities because of a health problem in past 2 weeks (Adj $\mathrm{OR}=0.54$; 95\%CI: $0.35,0.85$ ). Holding a private health plan was independently associated with a greater number of visits to a doctor in past 12 months $\left({ }_{\text {Adj }} \mathrm{OR}=1.62 ; 95 \% \mathrm{CI}: 1.02,2.62\right.$ for those who reported $\geq 4$ visits), as well as with use of higher numbers of prescribed med- 
Distribution of selected indicators of health status among older adults, according to private health plan status.

Bambui, Minas Gerais State, Brazil, 1997.

\begin{tabular}{|c|c|c|}
\hline \multirow[t]{2}{*}{ Indicator of health status } & \multicolumn{2}{|c|}{ Private health plan (\%) } \\
\hline & Yes $(n=310)$ & No $(n=1,296)$ \\
\hline \multicolumn{3}{|l|}{ Self rated health in past 6 months } \\
\hline Bad/very bad & 17.7 & 26.2 \\
\hline Reasonable & 49.0 & 45.7 \\
\hline Very good/good & 32.6 & 21.1 \\
\hline Not informed (proxy respondent) & 0.7 & 6.8 \\
\hline \multirow[t]{2}{*}{ Nor informed } & 0.0 & 0.2 \\
\hline & \multicolumn{2}{|c|}{$p^{\prime}<0.001$} \\
\hline \multicolumn{3}{|l|}{ Unable to perform one or more $A D L^{*}$} \\
\hline No & 97.0 & 94.8 \\
\hline \multirow[t]{2}{*}{ Yes } & 2.9 & 5.2 \\
\hline & \multicolumn{2}{|c|}{$p=0.083$} \\
\hline \multicolumn{3}{|l|}{ Level of difficulty to walk 300 meters } \\
\hline Unable/much & 13.6 & 23.3 \\
\hline Some & 17.7 & 20.9 \\
\hline None & 68.7 & 55.5 \\
\hline \multirow[t]{2}{*}{ Not informed } & 0.0 & 0.3 \\
\hline & \multicolumn{2}{|c|}{$p^{\prime}<0.001$} \\
\hline \multicolumn{3}{|c|}{$\begin{array}{l}\text { Unable to perform routine activities because } \\
\text { of a health problem in past } 2 \text { weeks }\end{array}$} \\
\hline Yes & 10.3 & 18.6 \\
\hline No & 89.7 & 81.3 \\
\hline \multirow[t]{2}{*}{ Not informed } & 0.0 & 0.2 \\
\hline & \multicolumn{2}{|c|}{$p=0.002$} \\
\hline \multicolumn{3}{|l|}{ Stayed in bed in past 2 weeks } \\
\hline Yes & 5.5 & 11.3 \\
\hline No & 94.5 & 88.5 \\
\hline \multirow[t]{2}{*}{ Not informed } & 0.0 & 0.2 \\
\hline & \multicolumn{2}{|c|}{$p=0.007$} \\
\hline \multicolumn{3}{|c|}{ Report of medical diagnosis of coronary heart disease } \\
\hline Yes & 10.3 & 10.9 \\
\hline No & 89.0 & 88.0 \\
\hline \multirow[t]{2}{*}{ Not informed } & 0.7 & 1.1 \\
\hline & \multicolumn{2}{|c|}{$p=0.696$} \\
\hline \multicolumn{3}{|c|}{ Report of medical diagnosis of diabetes } \\
\hline Yes & 12.9 & 11.1 \\
\hline \multirow[t]{2}{*}{ No } & 87.1 & 88.9 \\
\hline & \multicolumn{2}{|c|}{$p=0.373$} \\
\hline \multicolumn{3}{|c|}{ Report of medical diagnosis of other chronic condition } \\
\hline Yes & 57.7 & 55.6 \\
\hline \multirow[t]{2}{*}{ No } & 42.3 & 44.3 \\
\hline & \multicolumn{2}{|c|}{$p=0.501$} \\
\hline
\end{tabular}

* Activities of daily living (bathing, dressing, transferring, using the toilet of eating) $p=p$ value (Pearson's chi square test)

$p^{\prime}=p$ value (chi square for linear trend) 
Distribution of seropositivity for Trypanosoma cruzi and other health conditions among older adults, according to private health plan status. Bambui, Minas Gerais State, Brazil, 1997.

\begin{tabular}{lccc}
\hline $\begin{array}{l}\text { Seropositivity for } T \text { cruzi } \\
\text { and other health condition }\end{array}$ & $\begin{array}{c}\text { Pes }(\mathrm{n}=298) \\
\text { \% or median }(\mathrm{p} 25-\mathrm{p} 75)\end{array}$ & $\begin{array}{c}\text { p or median }(\mathrm{p} 25-\mathrm{p} 75) \\
\text { No }(\mathrm{n}=1,196)\end{array}$ \\
\hline Seropositive for T. cruzi & $24.9 \%$ & $40.9 \%$ & $\mathrm{p}<0.001$ \\
Median systolic blood pressure & $135(122-148)$ & $135(122-151)$ & $\mathrm{p}^{\prime \prime}=0.218$ \\
Median diastolic blood pressure & $82(75-90)$ & $82(75-91)$ & $\mathrm{p}^{\prime \prime}=0.254$ \\
Total cholesterol & $227(203-262)$ & $228(199-263)$ & $\mathrm{p}^{\prime \prime}=0.834$ \\
HDL cholesterol & $47(38-58)$ & $47(39-57)$ & $\mathrm{p}^{\prime \prime}=0.937$ \\
Trygliceride & $132(94-189)$ & $130(90-182)$ & $\mathrm{p}^{\prime \prime}=0.265$ \\
Body mass index & $25.5(22.9-28.5)$ & $24.6(21.4-27.8)$ & $\mathrm{p}^{\prime \prime}=0.001$ \\
\hline
\end{tabular}

p25 $=25$ percentile

p75 = 75 percentile

$p=p$ value (Pearson's chi square test)

$\mathrm{p}^{\prime \prime}=\mathrm{p}$ value (Wilcoxon rank test)

Table 4

Distribution of indicators for the use of health-care services among older adults, according to private health plan status. Bambui, Minas Gerais State, Brazil, 1997.

\begin{tabular}{|c|c|c|}
\hline \multirow[t]{2}{*}{ Characteristics } & \multicolumn{2}{|c|}{ Private health plan (\%) } \\
\hline & Yes $(n=310)$ & No $(n=1,296)$ \\
\hline \multicolumn{3}{|c|}{ Number of visits to a doctor in past 12 months } \\
\hline None & 15.2 & 20.4 \\
\hline $1-3$ & 47.7 & 48.8 \\
\hline \multirow[t]{2}{*}{$\geq 4$} & 37.1 & 30.9 \\
\hline & \multicolumn{2}{|c|}{$p^{\prime}=0.010$} \\
\hline \multicolumn{3}{|c|}{ Number of hospitalizations in past 12 months } \\
\hline None & 80.0 & 76.8 \\
\hline 1 & 16.1 & 15.4 \\
\hline \multirow[t]{2}{*}{$\geq 2$} & 3.9 & 7.8 \\
\hline & \multicolumn{2}{|c|}{$p^{\prime}=0.056$} \\
\hline \multicolumn{3}{|c|}{$\begin{array}{l}\text { Number of prescribed medications used } \\
\text { in past } 3 \text { months }\end{array}$} \\
\hline None & 14.5 & 21.6 \\
\hline $1-2$ & 25.8 & 29.5 \\
\hline $3-4$ & 29.7 & 28.0 \\
\hline \multirow[t]{2}{*}{$\geq 5$} & 30.0 & 20.9 \\
\hline & \multicolumn{2}{|c|}{$p^{\prime}<0.001$} \\
\hline \multicolumn{3}{|c|}{$\begin{array}{l}\text { Number of non-prescribed medications used } \\
\text { in past } 3 \text { months }\end{array}$} \\
\hline None & 85.5 & 82.3 \\
\hline 1 & 10.3 & 12.5 \\
\hline \multirow[t]{2}{*}{$\geq 2$} & 4.2 & 5.2 \\
\hline & \multicolumn{2}{|c|}{$p^{\prime}=0.010$} \\
\hline
\end{tabular}

$p^{\prime}=p$ value (chi square for linear trend) 
ication $\left(_{\text {Adj }} \mathrm{OR}=1.75 ; 95 \% \mathrm{CI}\right.$ : $1.09-2.82$ and ${ }_{\text {Ad- }}$ jOR $=2.81$; 95\%CI: $1.71-4.63$ for those who reported $3-4$ and $\geq 5$ medicines used in past 3 months, respectively).

Family income was consistently associated with holding a private health plan after adjustments for indicators of health status (self rated health and a report of inability to perform routine activities because of a health problem in past 2 weeks) and indicators of the use of health-care services (number of visits to a doctor in past 12 months and number of prescribed): $\mathrm{OR}=2.94$ (95\%CI: $1.89-4.61)$ and OR = 8.01 (95\%CI: 5.29-12.12) for those whose monthly family income were 4.0-5.9 and $\geq 6.0$ Brazilian minimum wages, respectively.

Older adults covered by private medical plan reported less dissatisfaction when seeking medical care than those under exclusive public covering ( $29.1 \% v s .54 .8 \%$, respectively), and they complained of less difficulties to: pay for medical care (9.0 vs. $17.2 \%)$, make a medical appointment because of existing lines (10.8 vs. $21.3 \%$ ) or other problems (25.4vs. 32.4\%) (p < 0.001 ) (Figure 1). Those covered by private plan also reported less dissatisfaction when needing a medication (44.9 vs. $68.7 \%$ ) and they complained of less difficulties in buying medicine (25.2 vs. 47.1) or other problems (6.1 vs. 8.2\%) $(\mathrm{p}<0.001)$ (Figure 2).

\section{Discussion}

In this population based study we found that number of visits to a doctor and the number of prescribed medications used were higher among elderly people holding private supplemental health plans. We did not find evidence of adverse health selection among those with private health plans.. On the contrary, those under exclusive SUS public coverage presented some evidence of having worse health status.

Previous work examining the presence of adverse health selection among elderly people with private coverage has provided conflicting results (Eggers \& Prihoda, 1982; Hellinger, 1995; Hurd \& McGarry, 1997; Wolfe \& Godderis, 1991). An important concern regarding these results was that studying the relationship between private purchase and health without controlling the economic status could obscure any adverse selection (Hurd \& McGarry, 1997). In our study, two indicators of worse health status (self rated health as bad or very bad and inability to perform routine activities due to a health problem in prior 2 weeks) were found to be associated with exclusive public SUS cover-

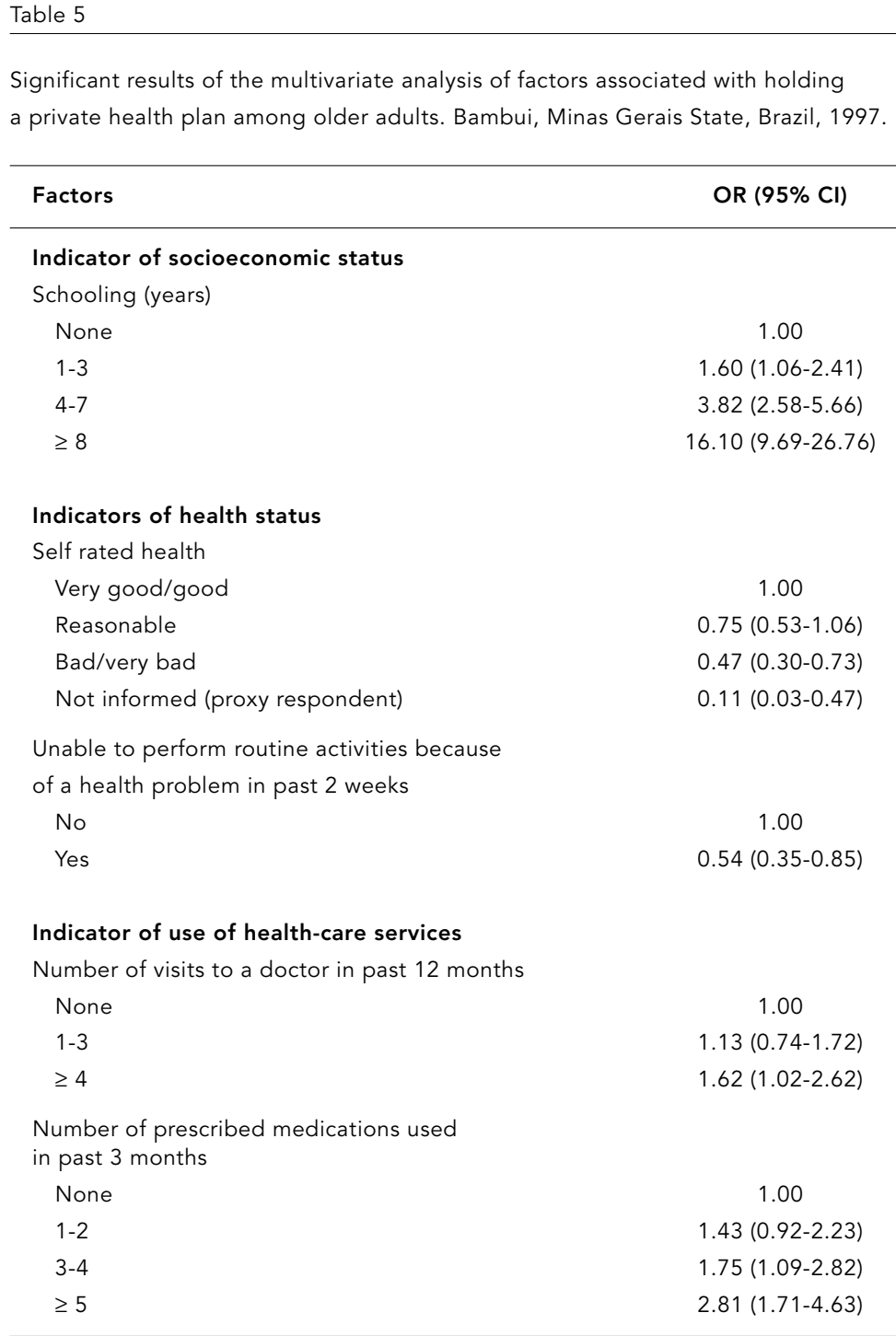

OR $(95 \% \mathrm{Cl})=$ Odds ratios and $95 \%$ confidence intervals adjusted by multiple logistic regression analysis for all variables listed on the table (1,596 individuals participated in the final analysis)

age after adjustment for several confounding variables, including education which was highly correlated with family income.

In our study, health status could not explain lower frequency of visits to a doctor and lesser number of prescribed medications of older adults with exclusive public coverage. On the contrary, out results indicate that those under exclusive SUS coverage had worse health indicators and, as a consequence, one could speculate that they had more needs for health services. Their lower number of visits to a doctor in comparison with those with private health plan might be partly explained by problems of having access to medical care, that is: (1) difficulty to make a medical appointment because 
Figure 1

Distribution of main reasons for dissatisfaction identified by older adults when seeking medical care, according to private health plan status. Bambuí, Minas Gerais State, Brazil, 1997.

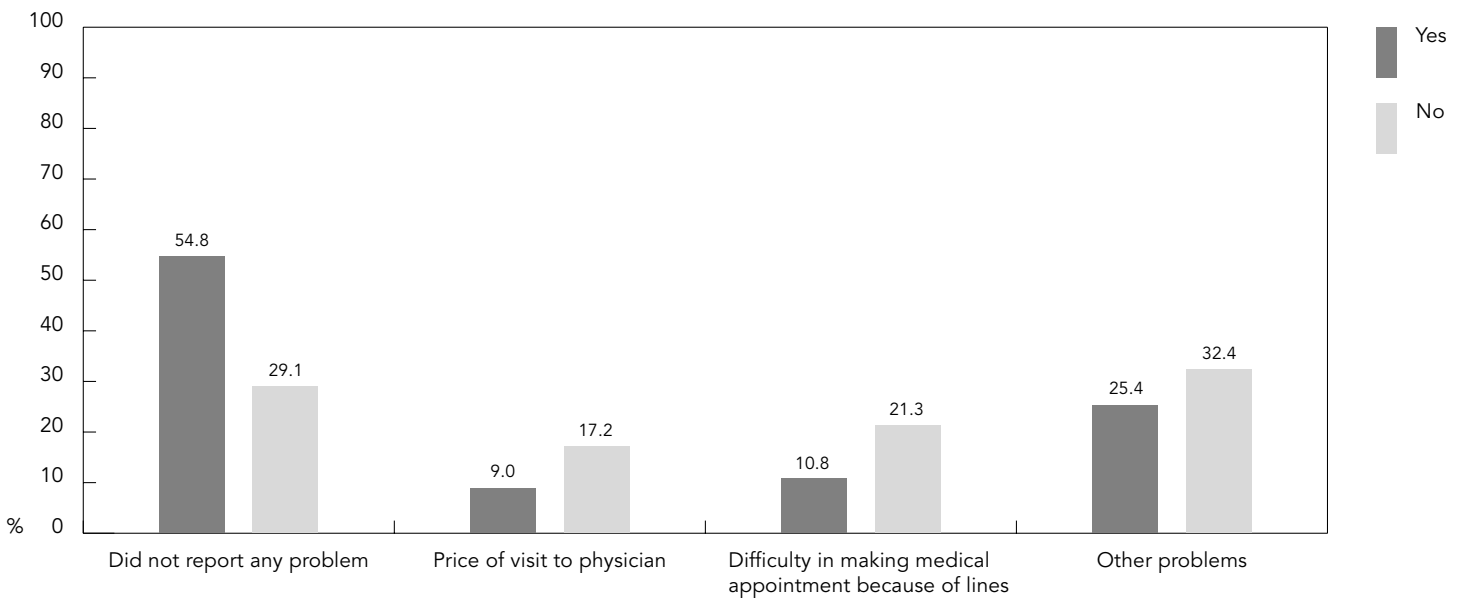

Figure 2

Distribution of main reasons for dissatisfaction identified by older adults when attempting to obtain medication, according to private health plan status. Bambuí, Minas Gerais State, Brazil, 1997.

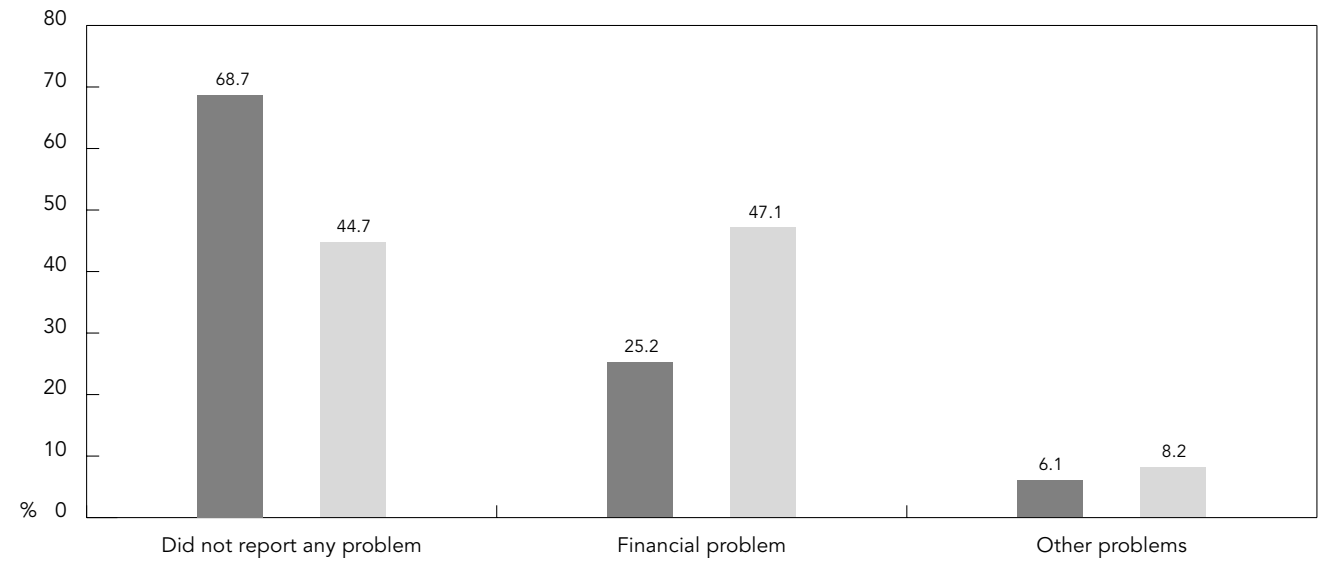


of the existing lines, (2) consultation price, and (3) other problems. Existing lines are of a managerial order and could be solved with better administration of public health services. The second complain (price of medical services), reported by $17.2 \%$ of the aged population who did not have private health plan, suggest that they attempt to obtain other forms of medical care in private surgeries, but have economic difficulties to purchase such care.

Financial problems were also appointed as the main difficulty to obtain medication. Even though this complaint was more frequent among the aged under exclusive SUS public coverage $(47.1 \%)$, it was also reported by those who had private health plan $(25.2 \%)$.

Years of schooling and monthly family income were both strongly associated with private health plan status. This result, together with no evidence of adverse health selection in our study, agrees with previous observations in developed countries that the explanation for the purchase of supplemental coverage is the economic resource of the elderly (or his family), not health (Hurd \& McGarry, 1997; Sloan \& Conover, 1998).

The proportion of elderly holding private health plan in our study is small (around 20\%) and similar to that estimated for Brazil (PAHO, 1999). In a study developed in a large Brazilian city (Rio de Janeiro), around $57-88 \%$ of the aged had private health plan, this proportion being greater in high income areas of the city (Pinheiro \& Travassos, 1999). The results of our study are consonant with the low socioeconomic level of the study community.

Regarding methodological aspects, several steps were followed to minimize bias in this study (Lima-Costa et al., 2000): internal validity, information double blinded, assessment of the reliability of the data gathered, standardized procedures and instruments, and inclusion in data analysis of several potential confounding variables. The choice of exploratory variables in this work took into consideration their importance as predictors of health care use (Hurd \& McGarry, 1997; Mor et al., 1994; Pacala et al., 1993) and mortality (Bernard et al., 1997; Korten et al., 1999; Menec et al., 1999; Penninx et al., 1997). Nevertheless, one cannot be sure that an unknown confounding variable has not been included in the analysis.

\section{Conclusions}

Summarizing, our results showed that older adults in the studied community were highly dependent on the public health system. In comparison with those with private health plan, the $80 \%$ of the aged who were under exclusive public SUS cover presented some evidence of having worse health status, reported less visits to a doctor, and used lower number of prescribed medications. Confirming previous observations from developed countries (Hurd \& McGarry, 1997; Sloan \& Conover, 1998), we found that the explanation for holding a private health plan in the studied population was economic, not health. In general, even though the aged who had only public health coverage complained more in relation to medical care $(70.9 \%$ reported some kind of problem), an important proportion (45.2\%) of the aged people with supplemental health plan also presented some kind of complaint. Another worrying factor was the difficulty to acquire medicines because of financial problems: $47.2 \%$ and $25.2 \%$ of those without and with supplemental health plan reported financial problems, respectively. To our knowledge, this study represents the first effort to examine the associations between private health plan status, health care services and medication use, as well as adverse health selection among older adults in a Brazilian community. Further investigations are needed to verify whether our results can be generalized to other communities of the country.

\section{Acknowledgments}

This work was sponsored by the Financiadora de Estudos e Projetos (FINEP), Rio de Janeiro, Brazil (Process 66940009-00). The Conselho Nacional de Desenvolvimento Científico e Tecnológico (CNPq) sponsored authors' scholarships (Processes 520337/96-4, 301056/ 94-3 142974/97-8 and 300908/95-4). 


\section{References}

ANONYMOUS, 1993. The fifth report of the Joint National Committee on Detection, Evaluation, and Treatment of High Blood Pressure (JNC V). Archives of Internal Medicine, 153:154-183.

ARMITAGE, P. \& BERRY, G., 1987. Statistical Methods in Medical Research. Oxford: Blackwell Scientific Publication.

BERNARD, S. L.; KINCADE, J. E.; KONRAD, T. R.; ARCURY, T. A.; RABINER, D. J.; WOOMERT, A.; DEFRIESE, G. H. \& ORY, M. G., 1997. Predicting mortality from community surveys of older adults: The importance of self-rated functional ability. Journal of Gerontology. Series B, Psychological Sciences and Social Sciences, 52:S15-63.

COHEN, R. A.; BLOOM, B.; SIMPSOM, G. \& PEARSONS, E., 1997. Access to health care. Part 3: Older adults. Vital and Health Statistics. Series 10. Data from the National Health Survey, 198:1-32.

DATASUS (Departamento de Informática do SUS), 1996. Movimento de Autorizações de Internações Hospitalares. CD-ROM. Brasília: Ministério da Saúde.

EGGERS, P. W. \& PRIHODA, R. H., 1982. Pre-enrollment reimbuserment: Patterns of Medicare beneficiaries enrolled at-risk HMOs. Health Care Financial Review, 4:55-74.

GREENLAND, S., 1989. Modeling and variable selection in epidemiologic analysis. American Journal of Public Health, 79:340-349.

HELLINGER, F. J., 1995. Selection bias in HMOs and PPOs: A review of the evidence. Inquiry, 32:135142.

HOSMER, D. W. \& LEMENSHOW, S., 1989. Applied Logistic Regression. New York: John Wiley and Sons.

HURD, M. D. \& McGARRY, K., 1997. Medical insurance and the use of health care services by the elderly. Journal of Health Economics, 16:129-154.

IBGE (Fundação Instituto Brasileiro de Geografia e Estatística), 1996. Censos Demográficos: 1991 1996. Rio de Janeiro: IBGE.

KORTEN, A. E.; JORM, A. F.; JIAO, Z.; LETENNEUR, L.; JACOMB, P. A.; HENDERSON, A. S.; CHRISTENSEN, H. \& RODGERS, B., 1999. Health, cognitive and psychosocial factors as predictors of mortality in an elderly community sample. Journal of Epidemiology and Community Health, 53:83-88.

LIMA-COSTA, M. F. F.; BARRETO, S. M.; GUERRA, H. L.; FIRMO, J. O. A, UCHOA, E. \& VIDIGAL, P. G., 2001. Ageing with Trypanosoma cruzi infection in a community where transmission has been interrupted: Results of the Bambui Health and Ageing Study. International Journal of Epidemiology, 30:887-893.

LIMA-COSTA, M. F. F.; UCHOA, E.; GUERRA, H. L.; FIRMO, J. O. A.; VIDIGAL, P. G. \& BARRETO, S. M., 2000. The Bambuí Health and Ageing Study (BHAS): Methodological approach and preliminary results of a population-based cohort study of the elderly in Brazil. Revista de Saúde Pública, 34:126-135.
LINK, C. R.; LONG; S. H. \& SETTLE, R. P., 1980. Cost sharing, supplementary insurance and health services utilization among the Medicare elderly. Health Care Financing Review, 2:25-31.

McCALL, N. T.; RICE, J.; BOISMIER, J. \& WEST, R., 1991. Private health insurance and medical care utilization: Evidence from the Medicare population. Inquiry, 28:276-287.

MENEC, V. H.; CHIPPERFIELD, J. G. \& PERRY, R. P., 1999. Self-perception of health: A prospective analysis of mortality, control, and health. Journal of Gerontology. Series B, Psychological Sciences and Social Sciences, 54:P85-93.

MOR, V.; WILCOX, V. \& RAKOWSKI, W., 1994. Functional transitions among the elderly: Patterns, predictors, and related hospital use. American Journal of Public Health, 84:1274-1280.

NELSON, L. M.; LONGSTRETH, W. T.; KOPSELL, T. D. \& VAN BELLE, G., 1990. Proxy respondents in epidemiologic research. Epidemiologic Reviews, 12: 71-86.

OPAS (Organização Pan-Americana de Saúde)/OMS (Organização Mundial de Saúde), 1998. A Saúde no Brasil. Brasília: Escritório de Representações no Brasil, OPAS.

PACALA, J. T.; BOULT, C. \& BOULT, L., 1993. Predictive validity of a questionnaire that identifies older persons at risk for hospital admission. Journal of the American Geriatric Society, 43:374-377.

PAHO (Pan-American Health Organization), 1999. Basic Country Health Profiles for the Americas. Brazil: Health Systems and Services Country for Brazil. Agosto $2000<\mathrm{http}$ ://www.americas. health-sector-reform.org/english/brapen.pdf>.

PENNINX, B. W.; VAN TILBURG, T.; KRIEGSMAN, D. M.; DEIGER, D. J.; BOEHE, A. J. \& VAN EIJK, J. T., 1997. Effects of social support and personal coping resources on mortality in older age: The Longitudinal Aging Study Amsterdam. American Journal of Epidemiology, 146:510-519.

PINHEIRO, R. S. \& TRAVASSOS, C., 1999. Estudo da desigualdade na utilização de serviços de saúde por idosos em três regiões da cidade do Rio de Janeiro. Cadernos de Saúde Pública, 15:487-496.

SLOAN, F. A. \& CONOVER, C. J., 1998. Life transitions and health insurance coverage of the near elderly. Medical Care, 36:110-125.

STATA CORPORATION, 1997. Stata Statistical Software: Release 6.0. College Station: Stata Corporation.

WOLFE, J. R. \& GODDERIS, J. H., 1991 Adverse selection, moral hazard, and wealth effect in the medigap insurance market. Journal of Health Economics, 10:433-459.

WHO (World Health Organization), 1998. Population Ageing: A Public Health Challenge. Geneva: WHO.

Submitted on 23 October 2000

Final version resubmitted on 26 January 2001

Approved 8 April 2001 